\title{
Liveboard Media Development in Learning Réception Ecrite Débutante
}

\author{
Dewi Tri Wibowo ${ }^{1}$, Hesti Fibriasari ${ }^{2}$, Tansa Trisna ${ }^{3}$ \\ ${ }^{1,2,3}$ French language education, Faculty of languages and arts, Universitas Negeri Medan, Medan, Indonesia \\ Email:dewitriwibowo25@gmail.com, hestifibriasari@ymail.com,tansatrisna@unimed.ac.id
}

\begin{abstract}
This study aims to test the feasibility and develop Liveboard Media into a learning video product and study room containing Se Presenter material (Introducing yourself) in French. The method used in this research is the Research and Development method. In this study using 3 stages, namely Analyze, Design and Development. The results of this study indicate that the development of liveboard media in Réception Écrite Débutante learning is considered appropriate/good by showing an average score of $82.7 \%$.
\end{abstract}

Keywords: Liveboard, media, Reception ecrite.

\section{INTRODUCTION}

Learning a language is important for humans to increase their knowledge. The exact language learning they get will affect their ability in four skills. For 2020 FBS Unimed students who study French in the Réception Ecrite Debutante course, there are $74.4 \%$ of 39 students who complain that learning French online is difficult. The difficulties they face are caused by several factors, namely the lack of reading comprehension and reading comprehension in French, the less varied media and the unsupported network.

Based on the results of the needs analysis questionnaire that the researchers conducted in November 2020 on the implementation of classroom learning, a description was obtained that (1) Students still need varied learning media (2) Each student has one of the technological tools such as computers, laptops or cellphones to support online learning (3) When studying the online Reception Ecrite course, never use Liveboard media. (4) students become less motivated in learning French. Based on the results of the analysis of the problems above, a temporary conclusion can be made that the main factor causing the low French.

One of the media that is considered appropriate to overcome this problem is the development of Liveboard media as a medium for learning French online. This is because Liveboard is a whiteboard application that is able to collaborate in audio-visual, which can be used for teaching, drawing, and sketching and can be accessed anywhere and anytime. This media will eventually produce a learning video. Furthermore, the use of this media has never been used by a French language education study program lecturer in the Reception Ecrite Debutante course and should be able to be applied in learning French.

\section{METHOD}

This study uses the R\&D method. Research and development is an activity to develop a product or modify an existing product, which involves systematic steps to make it more perfect and more attractive than before. The research steps according to Robert Maribe Branch (2009) using the ADDIE model consist of 5 stages, namely: Analyze, Design, Development, Implementation, Evaluate. Of the 5 stages, in this study only used 3 stages due to time constraints in the study period. The steps of $\mathrm{R} \& \mathrm{D}$ research can be seen in the image below:

\begin{tabular}{|c|}
\hline $\begin{array}{l}\text { Analyze } \\
\text { Process analyze/product management plan (estimated } \\
\text { research duration } 2 \text { months, location, cost, etc.). Conducted } \\
\text { data analysis conducted for Part } 1 \text { as initial data. The } \\
\text { resource persons involved are lecturers and students. }\end{array}$ \\
\hline$\downarrow$ \\
\hline $\begin{array}{l}\text { Design } \\
\text { The process of drafting the concept to design media to } \\
\text { support learning French for Se Presenter. }\end{array}$ \\
\hline$\downarrow$ \\
\hline $\begin{array}{l}\text { Development } \\
\text { The process of developing Liveboard media to become } \\
\text { learning media with the final result of learning videos } \\
\text { and study rooms. And test the media feasibility by } \\
\text { Validation of media experts and material experts. }\end{array}$ \\
\hline
\end{tabular}

Figure 1. Research \& development stages 


\subsection{Research \& development stages}

The five stages of the ADDIE model Research and development according to Robert Maribe Branch (2009) which will be described below, this study uses 3 steps as follows:

\subsubsection{Analysis Stage}

The analysis step is carried out by a researcher to collect various sources of relevant data and information. The first step to take is to distribute needs analysis questionnaires to be placed in chapter 1 . Information on needs analysis comes from students who provide questionnaires. In the questionnaire, the researchers analyzed where the difficulties were and what they needed to solve their problem of learning French. The results of this phase are a summary of the analysis.

\subsubsection{Design stage}

The design stage is carried out by designing and planning French language learning materials using the Presenter material in accordance with the liveboard media. This activity is a systematic process that will begin by determining the purpose of the media, materials, content, etc., as well as determining who the media is for (lecturers and students). The results of this stage are an overview of the research.

\subsubsection{Development stage}

After the planning stage, the researcher will carry out the development stage. The materials we collect include French language books containing material (Se Presenter), the books used are Precis de Grammaire Books, Edito Francais Methods A1 and Tendance A1, Liveboard Media, supporting images and others that may be needed. Then it was developed into a learning media in the form of a teaching video that already contained Se Presenter material. Develop media, validate media and material experts, and make revisions. The product revision process is included based on comments and suggestions from media experts and material experts to make it better than before based on what students need.

\subsection{Data collection technique}

To find out data collection techniques, researchers used data collection techniques as follows:

\subsubsection{Questionnaire}

According to Sugiyono (2017: 199) "Questionnaire is a data collection technique that consists of giving a series of questions or statements to respondents to be answered". Questionnaires using a Likert scale are distributed for research objects, namely semester 1 students through Google Form and for both validators through written questionnaires. The questionnaires were analyzed to support and result from the Liveboard media development research. The results of the analysis of student needs feel interested and happy if there is this media development. Students need more varied media to study online.

\subsection{Instrument validation}

The instrument was validated by 2 experts, namely media experts and material experts to see existing weaknesses and shortcomings for input/comments.

This is done to increase the use of media so that it is of good quality. This research was conducted at the French Education Study Program FBS-UNIMED. The object of research and the source of data are first semester students who take the Reception Ecrite Debutante course.

\section{RESULT AND DISCUSSION}

Student problems in the Reception Ecrite Debutante course are based on the following questionnaire: Students have difficulty learning French online $(74.4 \%)$ for several reasons such as low comprehension of texts and difficulty in reading French texts and networks. The material they want to develop is "Se Presenter" (41\%). Furthermore, the use of learning media during teaching and learning is very important for students (84.6\%). When online learning Reception Ecrite Debutante had previously used media such as: Zoom, Google Meet, Google Classroom, Sipda, and Books and they still needed more varied media around $(92.3 \%)$ to understand this course to make it more interesting to learn college student.

Therefore, we found that the learning media in the Reception Ecrite Debutante course still needed to be developed in order to enrich the further learning media in this course, especially in the French Language Education Study Program FBS-UNIMED.

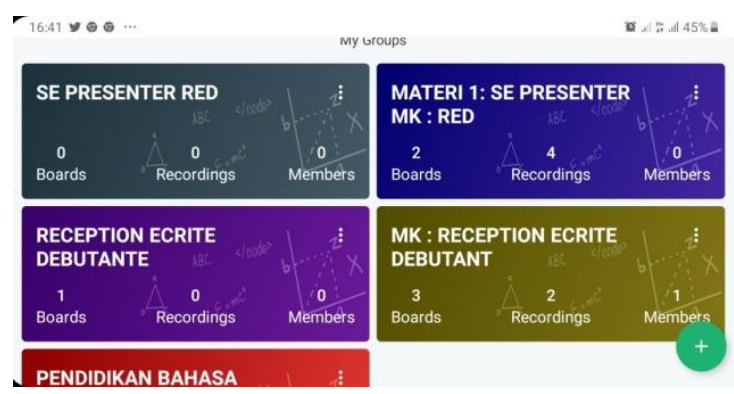

Figure 2. Liveboard Study Room Display 


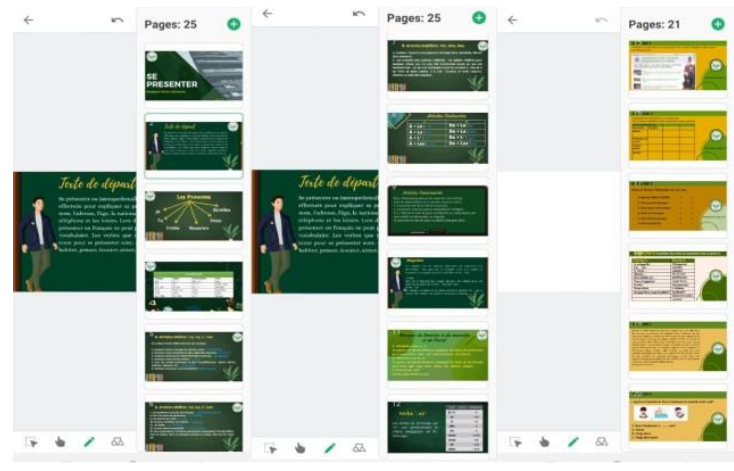

Figure 3. Story Board

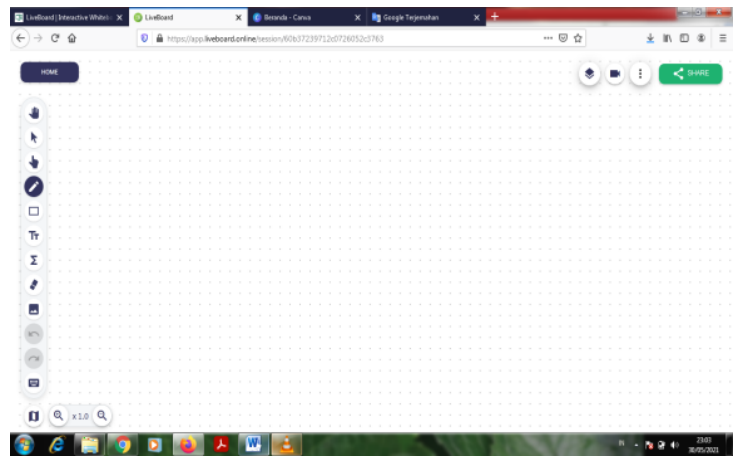

Figure 4. Layer Before development

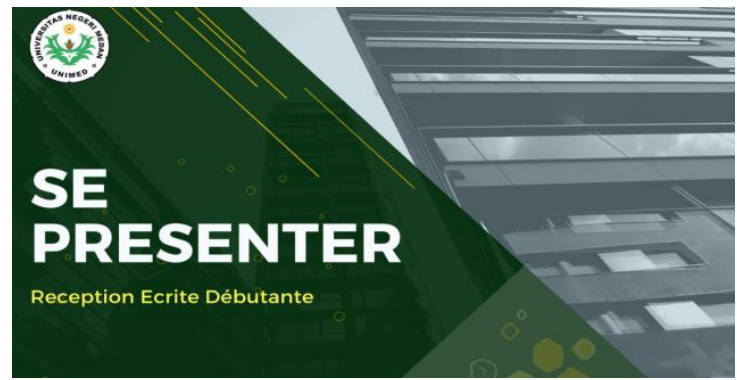

Figure 5. Initial View

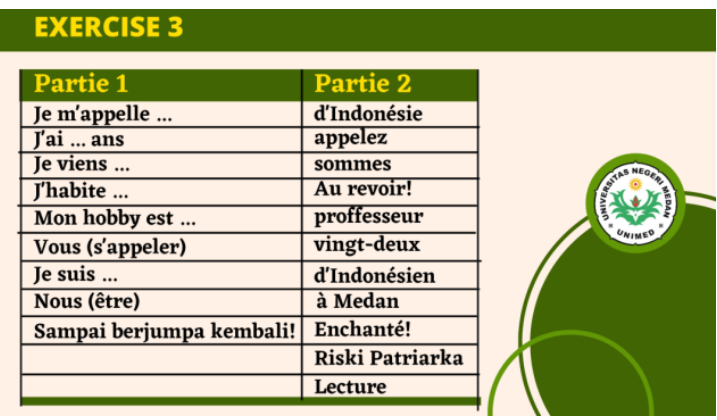

Figure 6. Exercise

The feasibility score of learning media is measured based on the validation of material experts and media experts. The data obtained from the expert is descriptive quantitative data using a Likert scale. Material validation is based on 4 aspects: the suitability of the material with the RPS, the accuracy of the material and the update of the material. Before the teaching material is feasible, several revisions are made on the basis of reference books and expert opinions so that an average score of 80 "Agrees / Good".
Media validation is based on 4 aspects: coloring, use of words and language, on-screen display, sound animation and room display. Before the media was deemed worthy, we made several revisions based on expert opinion so that we got an average score of 85.4 "Agree/Good". Due to this, Liveboard is one of the online learning solutions that can be used, because when students have network difficulties, they can see it after students have a network because there are study rooms left and there are learning videos.

\section{CONCLUSION}

The relationship between data and theory obtained is all through data collection techniques. The following are some conclusions in this study, namely: The development of Liveboard media into Learning Videos and learning rooms is always under supervision and guidance by experts, namely material experts and media experts. The results showed that the average value of the material expert was $80 \%$ (agree/good) and the media expert was $85.4 \%$ (agree/good). Based on the results of the validation of material experts and media experts, the average score is $82.7 \%$, then the Liveboard media development in Reception Ecrite Debutante learning is said to be Valid / Appropriate.

\section{REFERENCES}

[1] Al Caraz, Marion, dkk.2016. Édito A1 Méthode de français. Italia:L.E.G.O.

[2] Aytaç, Taufan.2013. Interactive Whiteboard factor in Education: Students' points of view and their problems.Turkey: Academics Journals.

[3] Branch, Robert Maribe. 2009. Instructional Design : The ADDIE Approach. London: Springer.

[4] Burhendi, Feli Cianda Adrin, dkk.2020. The implementation of blended learning models based liveaboard against affective aspects in modern physics course. Indonesia:University of Muhammadiyah Prof. DR. Hamka.

[5] Chollet, Isabelle, Jean.2009.Précis de Grammaire. Paris. CLE International.

[6] Didier.2005.Cadre Europeen commun de reference pour les langues. Apprendre, Enseiigner, Evaluer. Prancis: Didier.

[7] Fibriasari, Hesti, dkk.2017. The Development of Learning Media Réception Écrite Élémentaire WEB-Based. Medan : Atlantis Press.

[8] Gallet, Anne.2009. Bescherelle Conjugaison Poche. Prancis : HATIER.

[9] Girardet, Jacky, dkk.2016. Tendances A1 Méthode de français. Italia : CLE International.

[10] Muliawati, inne. 2019. Pengembangan media pocket book untuk pembelajaran kosakata bahasa prancis level a1. Yogyakarta. 
[11] Tissera, Alicia, dkk. Les médias en tant qu'outils pédagogiques en classes de langue étrangère. Universidad Nacional de Salta.

[12] Umar. 2014. Media Pendidikan: Peran dan Fungsinya dalam Pembelajaran. Satin Jurai Siwo Metro. Volume 11.

[13] Panglindung,CharismaAlimnashadeq. 2015. Penggunaan Smart Board untuk pembelajaran bahasa Arab di MTs Yapi Pakem. Yogyakarta.

[14] Purwono, Joni, dkk.Edisi April 2014. Penggunaan media audio-visual pada mata pelajaran ilmu pengetahuan alam di sekolah menengah pertama negeri 1 pacitan. UNS.
[15] Virnia, Dwi Vicky Suges. 2019. Upaya peningkatan penguasaan kosakata bahasa prancis melalui teknik permainan mistery bag pada peserta didik kelas $\mathrm{x}$ ipa 1 sma angkasa adisutjipto yogyakarta tahun ajaran 2018/2019. Yogyakarta.

[16] Https://man2sragen.sch.id/situs/detail

[17] berita/29 (diakses pada 17 desember 2020 pukul 11.59).

[18] Optimalisasi Liveboard Sebagai Media Pembelajaran.htm (diakses pada 17 desember 2020 pukul 11.48). 